\title{
JUSTICE IN THE COVID-19 ERA THROUGH THE PRISM OF JUDICIAL POWER
}

LA JUSTICIA EN LA ERA DEL COVID-19 A TRAVÉS DEL PRISMA DEL PODER JUDICIAL

Victor Gorodovenko*

Oleksandr Bondar**

Larysa Udovyka ${ }^{* * *}$

\begin{abstract}
The work is devoted to identifying the main problems in the field of the principle of legal proceedings in the context of the Covid-19 pandemic. The research applies the formal-legal, historical and legal, comparative and modeling methodology. The order and issues to be considered are as follows: in the first section, we will consider the challenges and threats to justice that emerged during the Covid-19 pandemic. In the second section, we will see the judicial experience during the pandemic in the context of the basic principles of the judiciary. In the third section, we examine the application of organizational and procedural principles of the judiciary during the pandemic crisis. In the final fourth section, we will assess the role of international judicial institutions and government bodies in optimizing the administration of justice in the context of the Covid-19 pandemic. As a result of the work, emphasizing the vulnerability of the judicial system and justice standards, the authors support the expansion of exchange of experience and cooperation not only at the state level but also at the level of professional communities of judges, in particular with the members and judges of the European Commission for the Effectiveness of
\end{abstract}

\footnotetext{
* Doctor of Legal Science, Professor, Judge of the Constitutional Court of Ukraine (Kyiv, Ukraine). https://orcid.org/0000-0001-6002-4192. horodoveko@ccu.gov.ua

** Doctor of Legal Science, Professor, 1st Vice-Rector of Zaporizhzhia National University (Zaporizhzhia, Ukraine). https://orcid.org/0000-0003-0738-1232. al_bondar@ukr.net

*** Doctor of Legal Science, Associate Professor of Department of History and Theory of State and Law of Zaporizhzhia National University (Zaporizhzhia, Ukraine). https://orcid.org/0000-0001-9260-4474. lora.znu@gmail.com
} 
Justice, the Advisory Council of European Judges, and the European human rights courts.

Keywords: Rule of Law, Access to Justice, Covid-19 Pandemic, Principles of the Judiciary, Judicial Protection of Human Rights

Resumen: El trabajo está dedicado a identificar los principales problemas en el campo del principio de procedimiento judicial en el contexto de la pandemia Covid-19. La investigación usa los métodos formal legal, histórico y legal, análisis comparativo y modelización. El orden y los temas a considerar son los siguientes: en la primera sección, consideraremos los desafios y amenazas a la justicia que surgieron durante la pandemia de Covid-19. En la segunda sección, se verá la experiencia judicial durante la pandemia en el contexto de los principios básicos del poder judicial. En la tercera sección, examinamos la aplicación de los principios organizativos y procesales del poder judicial durante la crisis de la pandemia. En la cuarta sección final, evaluaremos el papel de las instituciones judiciales internacionales y los organismos gubernamentales en la optimización de la administración de justicia en el contexto de la pandemia Covid-19. Como resultado del trabajo, enfatizando la vulnerabilidad del sistema judicial y los estándares de justicia, los autores apoyan la expansión del intercambio de experiencias y cooperación no solo a nivel estatal sino también a nivel de comunidades profesionales de jueces, en particular con los miembros y jueces de la Comisión Europea para la Eficacia de la Justicia, el Consejo Asesor de Jueces Europeos, y los tribunales europeos de derechos humanos.

Palabras clave: Estado de derecho, acceso a la justicia, pandemia Covid19, principios del poder judicial, protección judicial de los derechos humanos

Summary. I. Introduction. II. Results and discussion. II.1. Challenges and Threats to Justice during the Covid-19 Pandemic. II.2. Justice in the Context of Basic Principles of the Judiciary. II.3. Justice in the Context of the Organizational and Procedural Principles of the Judiciary. II.4. Ongoing Work to Streamline the Administration of Justice in a Pandemic. III. Conclusions. References.

\section{INTRODUCTION}

On March 12, 2020, the World Health Organization declared Covid19 a pandemic. Its spread has led to an emergency not only in the field of public health in all countries of the world but has transformed their 
economic, political, social, informational, and other spheres, radically changed the global order.

The most obvious and painful were the economic consequences, first of all, the drop in GDP, the closure of enterprises in countries and borders, the fall in oil prices, the rise in prices for everyday products, and speculation in the market for certain goods. According to many experts, we are talking about a deep crisis of a global scale, which will take more than a decade to overcome. The Organization for Economic Cooperation and Development (2020) predicts the risk or not the most global economic crisis since the 2008 crisis. Pessimists argue that we are on the verge of a global depression, as bad as it was in the 1930s (Boot et al., 2020). Social consequences have become no less threatening, in particular, the growth of poverty, unemployment, crime, the reduction of the middle class, access to medical services, the massive closure of educational institutions, the spread of domestic violence. Among the political consequences, one should highlight, in particular, the complication of authoritarianism, the strengthening of state supervision, control, repressive measures, and ethnic nationalism under the slogans of combating the pandemic, the curtailment of civil liberties, a wave of censorship, and the radicalization of politics in general. All this in turn led to a drop in the level of trust in governments and state institutions.

The spread of the pandemic also has legal consequences at the international, European, and national levels, both in the field of lawmaking and law enforcement and law enforcement. The most complex and controversial was the impact of the pandemic on human rights and legal remedies for their protection. As UN Secretary-General Guterres (2020) aptly notes, the Covid-19 pandemic is a public health emergency, but it goes far beyond that. An economic, social, and human crisis is rapidly turning into a human rights crisis. Against the background of the spread of misinformation, the negative psychological consequences of isolation, the insufficiently responsible attitude of ordinary citizens to the Covid-19 pandemic, the spread of the phenomena of stigma, non-conformism, increased risks of insecurity of socially vulnerable segments of the population, crime, the crisis has acquired a complex, universal nature, threatens the fundamental values of European civilization, above all democracy and human rights.

The limitation of human rights can be traced in all countries of the world, has common and distinctive features, and largely depends on the characteristics of justice, requires reasonable and coordinated actions on the part of national states, supranational institutions, and bodies. Under such conditions, it is extremely important to unite efforts and expand cooperation of the European judicial community to ensure proper and impartial justice, 
joint search for optimal legal means based on universally recognized values and priorities, and at the same time take into account national characteristics. The justice system plays a critical role in both protecting human rights and mitigating the negative impact of the spread of the Covid-19 pandemic.

\section{RESULTS AND DISCUSSION}

\section{II.1. Challenges and Threats to Justice during the Covid-19 Pandemic}

In the context of the spread of the Covid-19 pandemic, justice in compliance with the principles of the judiciary is significantly complicated, requires significant efforts and additional legal, organizational, and material resources. The courts were faced with an extremely difficult question: the need to strike a balance between public safety and the right to a fair trial. International experts, judges, scientists draw attention to the fact that an emergency in the field of public health cannot be used as a pretext to institute the foundations of justice, human rights, and new legal means must be applied in strict compliance with human rights obligations (Council of Europe, 2020), above all, the rule of law and access to justice, which must be ensured in all circumstances (European Union Advisory Mission to Ukraine, 2020).

In the short term, the challenge for the sphere of national justice will be a significant increase in the burden on the courts in connection with the economic crisis, restrictions on the social, political, and cultural rights of citizens. Besides, «geopolitical competition and tensions» (Kupchan, 2020) can create additional pressures on the international system and impede necessary cooperation, collective rule-setting, and cross-border assistance. This prompts the need for a timely understanding of the problems that arise in the field of justice, a generalization of advanced foreign experience and optimal directions for its improvement, fruitful international cooperation, its proactive actions because it is part of the critical national infrastructure of each country.

It is quite natural that in the first report, "Access to justice and the Covid-19 pandemic" (Center on International Cooperation, 2020) prepared by The Pathfinders for Peaceful, Just and Inclusive Societies, several areas of activity for leaders of the justice system are highlighted, which are of priority, namely: (i) the fair implementation of emergency measures through independent verification of the adequacy of new activities; (ii) protecting people from violence; (iii) attracting people to partnership; (iv) minimizing the need for recourse to the formal justice system; (v) development of innovations and rational approaches to work, solving cases online or by 
phone; and (vi) protection of those who are at the forefront of the provision of justice services, among others.

It should be noted that the selection of directions is not exhaustive, and their list depends on the effectiveness of the judicial systems, their resource support, and national characteristics. In the difficult conditions of the spread of the Covid-19 pandemic, the vast majority of modern civilized states are making significant efforts to ensure justice, fair and reasonable settlement of disputes following international and European legal standards enshrined in such international legal acts as the General Declaration of Human Rights of 1948, the International Covenant on Civil and Political Rights 1966 (Articles 6, 9, 10, 14-16), Document of the 1990 Copenhagen Meeting of the OSCE Human Dimension Conference (Clause 5.5, 5.10-5.21), or the Basic Principles on the Independence of the Judiciary of 1985.

Fundamental in the administration of justice are the principles enshrined in the Universal Declaration of Human Rights: equality of all before the law (Article 7); everyone's right to effective judicial protection is exercised by a competent court established based on the law, that is, the right to justice (Article 8); and the right to an impartial and transparent public court (Article 10). In addition, the Convention for the Protection of Human Rights and Fundamental Freedoms (1950) provides in Article 6 that everyone has the right to a fair and public hearing within a reasonable time by an independent and impartial tribunal established by law, in the event of a dispute over his civil rights and obligations or in the presentation of any criminal accusations.

Analysis and generalization of the modern experience of the functioning of national judicial systems adhering to international standards of legal proceedings convincingly shows that the spread of the Covid-19 pandemic affects the content and implementation of the basic and organizational principles of the judiciary in different ways, some to a lesser extent, and others more essential. The limited amount of work makes it possible to dwell on those principles of the judiciary, the implementation of which is most transformed in the context of the spread of the pandemic.

\section{II.2. Justice in the Context of Basic Principles of the Judiciary}

In modern legal science, the fundamental principles of the judiciary include such as justice, rule of law, legality, independence, independence, completeness, transparency, and humanism. The content and interpretation of these principles differ depending on the type of legal thinking, scientific positions of scientists, legal consolidation of the principles, and their interpretation by international judicial institutions. Despite the differences 
in the views of scientists, there is a widespread point of view about the importance of observing the fundamental principles of the judiciary. The importance of observing the fundamental principles of the judiciary in the context of the spread of the Covid-19 pandemic lies primarily in the fact that they «together are aimed at achieving the objectives of the judicial branch of government, the main of which is the protection of human rights and fundamental freedoms» (Gorodovenko, 2012, p. 15). Also, the author adds:

«The principles of the judiciary play the role of backbone components, which, on the one hand, express its essence and purpose, and on the other hand, it is the foundation on which both the judicial system and the procedural form, the entire process of consideration and decision of legally significant cases by the court» (p. 16).

Thus, their observance is a criterion of justice in modern civilized, democratic countries.

The fundamental principle of the judiciary is justice, which lays its foundation. Fairness and justice will be the criteria by which people will assess the adequacy, appropriateness, and consequences of public health measures that will be taken by governments. People-centered justice has a leadership role to play in promoting justice and mitigating the impact of the pandemic. At the same time, quarantines pose several risks and sources of injustice, primarily for vulnerable groups of the population, elderly people suffering from domestic violence or other abuse. The rise in cases of domestic violence against the background of a decrease in the ability of its victims to react legally is already mentioned in many sources (North, 2020; Graham-Harrison, Giuffrida, Smith \& Ford, 2020; Gaviria, 2020). In some cases, a violation of the principles of justice, proportionality, and legal certainty is the introduction of significant fines and imprisonment for violation of quarantine measures. Such measures have been introduced in countries such as India, China, Spain, Italy, New Zealand, South Africa, and the United Kingdom (Brennan, 2020).

Equity is closely linked to the rule of law. The rule of law in the modern world is regarded as one of the highest democratic values, which forms the basis of international legal instruments in the field of human rights and justice. Without going into scientific discussions regarding the interpretation of the rule of law in foreign and domestic scientific thought, the lack of a human rights standard that would be generally accepted even among civilized countries, take into account the provisions of human rights that are most related to the rule of law, and should be protected in society, are: (i) the right to access to justice; (ii) the right to a legally competent judge; (iii) the right to be heard; (iv) impossibility of repeated criminal prosecution for the same crime; (v) the legal principle that measures that 
impose encumbrances should not be retroactive; (vi) the right to an effective remedy in any dispute; (vii) every person charged with a crime enjoys the presumption of innocence until proven guilty; and (viii) the right to a fair trial; there must be a fair and open hearing, without bias, and there must be a reasonable time frame within which the case must be heard and decided on (Seregin, 2015).

Thus, the observance of the principle of the rule of law as fundamental in ensuring and protecting human rights requires compliance with several requirements by the judicial authorities. Meanwhile, the imposition by governments of countries of unprecedented restrictions and strict quarantine measures complicates and makes it impossible (restriction of freedom of movement) the realization of the right to access to justice, the right to be heard, the right to a fair trial, open hearings, a reasonable time for consideration of cases, the observance of the principle of the rule of law as fundamental in ensuring and protecting human rights requires compliance with a number of requirements by the judicial authorities.

The right to access to justice as part of the rule of law cannot be simultaneously limited in a pandemic, it collides with the natural human right to life and a safe environment, the responsibility of ensuring which lies with the state. In such conditions, the most natural human right to life determines the necessary and fair balance between the human right to an environment safe for life and health and the right to a fair trial. At the same time, it is said about the need to ensure the health and safety of both citizensvisitors to courts and all employees of the justice system, requires the introduction of balanced security measures for safe distance in the premises of the court, consultations and explanations to all interested parties.

That is why the courts, in particular the European Court of Human Rights (hereinafter, "ECHR"), decided to develop and approve instructions for the work of the court in an unprecedented situation caused by the Covid19 pandemic for the period from March 16, 2020, to June 15, 2020, with a gradual return to normal conditions from May 11, 2020. Since the inception of this instruction, the court staff has been transferred to telecommuting, except those judges and secretariat staff whose presence was due to the need to ensure hearings and to receive and distribute documents (Supreme Court of Ukraine, 2020). At the same time, in many countries, appropriate and adequate measures were not taken promptly. In countries heavily affected by the pandemic, the number of sick justice workers or those in self-isolation already, significantly reduces the capacity of these systems. Judges and members of the judiciary face risks of infection in the performance of their duties and require additional measures (Centers for Disease Control and Prevention, 2019). Judges and members of the judiciary who are at the 
forefront of the provision of justice services require priority attention and priority when passing tests for diseases and vaccinations.

Along with the introduction of security measures during court hearings, the expansion of trials in the mode of videoconferences, the experience of foreign countries indicates the advisability of minimizing the need to turn to the formal justice system, in particular, by stopping detention for minor offenses, preventing eviction. In developing countries, the local population trusts both conventional and informal justice systems because their services are more readily available for those of the formal systems (Center on International Cooperation, 2020). The experience of the Netherlands and the United States is also positive, which has shown that direct contact between the parties to a dispute can dramatically reduce the number of formal procedures, while significantly saving time and money for the justice system (Bos, 2014). It should be noted that such measures should be used in the short term, and after the end of the public health crisis, the practice of applying proper procedures should be restored. In the context of criminal proceedings, alternative methods should be applied reasonably well.

It is also important to bring justice services closer to those who need them most. Therefore, with the aggravation of the pandemic in some countries, control over the situation in prisons was lost. «Prison riots have taken place in at least six countries since the virus was discovered, resulting in death and serious injury» (CrisisGroup, 2020). The failure of the courts can improperly lead to numerous human rights violations that can occur in prisons, detention centers, refugee camps, and, in some cases, may endanger their very lives. That is why, in many countries, prisoners are released who carry low risks to society, who are held in administrative proceedings or pretrial detention. Moreover, some even apply amnesties to prevent prisons from becoming the epicenter of the spread of the virus (World Health Organization, 2020; Office of the High Commissioner, 2020). Such measures can avert a humanitarian crisis and prevent serious human rights violations. It should be noted that the introduction of a state of emergency in many countries leads to the proliferation of authoritarianism and repressive measures, which are not always proportionate, necessary, nondiscriminatory, or even violate the principle of legality, which also applies to the fundamental principles of the judiciary. In this regard, the Consultative Council of European Judges stresses that the health emergency and the need to balance public safety and the enjoyment of fundamental rights and freedoms cannot be a pretext for the creation of "special courts", the appointment of "interim" judges, is a threat to the independence of the judiciary and can lead to the politicization of the courts (Council of Europe, 2020). 
Legality, as a fundamental principle of the judiciary, is seen in the independence of judges, their obedience to the law, the correct application of laws by the court when considering and resolving cases. Taking into account the legal positions of the ECHR, the court should not apply the law if, due to the circumstances of the case, it violates the inalienable human and civil rights. Meanwhile, hastily adopted laws, in many cases, restrict or even threaten civil liberties and human rights. In the long term, such laws can lead to «shrinking civil space and human rights» (Civicus, 2020). Besides, unprecedented restrictions on freedom of movement increased state supervision, and the use of personal data are in conflict with the right to privacy and confidentiality. In an emergency, the threat of abuse from those who impose new quarantine restrictions increases significantly. The justice system has an important role to play in determining the legality and proportionality of such measures that are imposed by national governments.

In the context of this attention, the practice of the bodies of constitutional jurisdiction of some countries deserves attention. Thus, the Constitutional Court of Bosnia and Herzegovina, in its decision of April 22, $2020 \mathrm{n}^{\circ}$ AR 1217/20, concluded that by two orders of the Federal Headquarters of Civil Protection, ${ }^{1}$ the right to freedom of movement was violated under article 11(3)(t) the Constitution of Bosnia and Herzegovina and Article 2 of Protocol $n^{\circ} 4$ to the Convention for the Protection of Human Rights and Fundamental Freedoms of applicants and all other persons in a similar factual and legal situation. The court ordered the Government of Bosnia and Herzegovina and the General Directorate of Civil Protection to take action following its decision within five days after its receipt (Constitutional Court of Bosnia and Herzegovina, 2020). In the opinion of the Constitutional Court, the contested measures do not comply with the requirement of "proportionality", which follows from Article 2 of Protocol $\mathrm{n}^{\circ} 4$ to the Convention for the Protection of Human Rights and Fundamental Freedoms, does not indicate, under which the assessment of the Federal Civil Protection Headquarters is based that the relevant groups, targeted activities have a greater risk of contracting or spreading Covid-19 infection. In addition, the possibility of introducing more lenient measures was considered, if such a risk is justified. Besides, the measures are not limited in time and there is no obligation to regularly review them to ensure their implementation as long as they are considered "necessary" for Article 2 of

\footnotetext{
${ }^{1}$ Orders of the Federal Headquarters of Civil Protection n ${ }^{\circ} 12-40-6-148-34 / 20$ of March 20,2020 and $n^{\circ} 12-40-6-34-1 / 20$ (on restricting the movement of persons under the age of 18 and persons under the age of 65 , in the territory of the Federation of Bosnia and Herzegovina).
} 
Protocol $\mathrm{n}^{\circ} 4$ to the Convention for the Protection of Human Rights and Fundamental Freedoms, or they will be decreased or terminated as soon as the situation permits.

The Constitutional Court of Bosnia and Herzegovina in its decision notes that even under a state of emergency it is necessary to observe the rule of law. Therefore, in such circumstances, the legislator must amend the laws in force and/or adopt special laws adapted to the crisis, which will give the competent authorities wider powers than those that the wills have according to the laws in force, to better and more efficiently respond to the crisis, such new laws or changes to existing laws must comply with the Constitution and international standard. The Constitutional Court of Bosnia and Herzegovina also notes that the new order sets the duration of the contested measures «until further notice». Such uncertainty about how long these measures will last is unacceptable. The introduced measures, especially those that significantly restrict human rights, guaranteed by the Constitution of Bosnia and Herzegovina and the Convention for the Protection of Human Rights and Fundamental Freedoms, should be limited in time (they can last exactly as long as necessary).

In the Republic of North Macedonia, the subject of the appeal was the restriction of the right to wages. The Constitutional Court of the Republic of Macedonia ruled on May 12, 2020, in two decisions $n^{\circ} 44 / 2020$ and 50/2020 on the suspension of the government decree on the reduction of wages to the minimum for all civil servants, including the president, parliament members, judges, prosecutors during the period of the state of emergency imposed by the pandemic. Arguing its position, the Constitutional Court of the Republic of Macedonia (2020) proceeded from the fact that the right to wages and the amount of wages of these persons are regulated by certain laws. According to the Constitutional Court of the Republic of Macedonia, the contested decree contradicts the Article 8.1.\$3 of the Constitution of the Republic of Macedonia, since they violate the fundamental value of the constitutional order of the Republic, the rule of law, and the legal certainty of citizens, all the aforementioned laws clearly state that the wages of these persons cannot be reduced by law or by a decision of the state organ. The contested decree creates a state of double application of various normative acts on the same thing: the actual and legal question of the amount of the salaries of the persons referred to in Article 2 of this decree. Thus, due to the emergence of a legal conflict with the current legislation, the Constitutional Court of the Republic of Macedonia considers that this regulation violates the principle of the rule of grass and legal certainty. Thus, the Constitutional Court of Bosnia and Herzegovina and the Constitutional Court of the Republic of Macedonia, when considering cases of restriction of human rights and 
freedoms and substantiating their decisions, take into account the principles of the rule of law, legality, and legal certainty.

The principle of transparency is becoming very important in administering justice in the context of the spread of the Covid-19 pandemic, which in general terms consists in the openness of trials and the simultaneous holding of closed court decisions in cases expressly provided for by law, public announcement of a court decision, ensuring free access to the announced court decision, openness to citizens of all aspects of the activities of judicial authorities and judicial self-government bodies. Openness, transparency, and accountability are essential in the face of temporary restrictions on human rights and the introduction of quarantine measures. In this case, we are talking about both the openness of the judiciary and the openness to communication, informing the public on legal issues. The priority role and capabilities of constitutional and other courts of the highest level.

\section{II.3. Justice in the Context of the Organizational and Procedural Principles of the Judiciary}

Protection of human rights and justice is impossible without observing the organizational principles of the judiciary, such as the availability of justice, the competence of the court, and ensuring the right to review a court decision. The introduction of strict quarantine measures significantly affected the availability of justice, the ability to appeal to citizens with the protection of violated rights. This is why the European Commission for the Efficiency of Justice draws attention to the need to ensure access to justice by other alternative means, such as: online services or the provision of information through court websites and other means of communication (telephone, email, etc.); expanding consultation and coordination work with all professionals in the justice sector (including lawyers, executive service workers, mediators); and providing special attention to vulnerable groups (in particular, women and children who face domestic violence, the elderly, or people with disabilities) or cases concerning serious economic situations.

An example can be the activity of courts in various countries. Thus, the Federal Court of Australia has moved all filing of applications, where this can be done practically on its system, eLodgment, which allows you to initiate actions online, as well as filing applications and documents on issues that have arisen. Likewise, New South Wales Courts has moved registrations to its online registry, which allows users to file court forms and access court decisions online. Whenever possible, hearings are replaced with audio and 
video conferencing using court-specific technologies or other platforms such as Microsoft Teams or Cisco WebEx (Legg \& Song, 2020).

In the UK, it was announced on March 27 that more than half of the courts and tribunals in England and Wales should be suspended. The Judicial Service has consolidated the work of all courts and tribunals in 157 priority courthouses and tribunals, i.e., $42 \%$ of the Court, to ensure the safety of everyone in the courts. The legal community has prepared a "heat map" that informs which courts are open, staffed and which courts are suspended. On March 31, 2020, the Courts Service also published a list of priorities, especially for district courts (Williams \& Johnson, 2020). Timely and comprehensive provision of the necessary information to court visitors solves several important problems, among them: ensures the implementation of the principles of access to justice and transparency; does not affect the introduced quarantine measures; and contributes to maintaining confidence in the judiciary.

Establishing and adhering to procedural time limits is essential to ensure effective judicial protection. The introduction of strict quarantine measures significantly influenced the procedural terms. That is why, in many countries, the procedural terms have been extended in several actions. Thus, the deadline for submitting applications to the ECHR increased by one month; then by another two months, a similar decision was introduced for the deadline for filing applications and other documents by the parties, the time limit for considering applications for referral of the case to the Grand Chamber increased by one month, respectively. The proceedings in all collegiums and the Grand Chamber of the ECHR continued remotely. In those cases in which oral hearings took place and the appropriate time frame was fixed, the approval of draft decisions by judges in electronic format was introduced, observing all the necessary conditions of confidentiality. In other cases, a written hearing is held using information technology, after which a preliminary date is set for a physical meeting of judges in compliance with quarantine standards to carry out the necessary procedural actions. In complex cases, videoconferencing has been introduced by remote participation of applicants, representatives of governments of other countries, third parties, and judges. And only a few hearings during the period of the most severe quarantine measures were postponed.

In the UK, on April 2, 2020, the practical Guideline PD51ZA (2020) entered into force, which extends the period during which the parties can agree to extend the data without court permission, from 28 to 56 days (Williams \& Johnson, 2020). British courts are actively promoting the idea of using digital tools. Remote hearings in the UK are predominantly held in civil and family cases but are not always supported by lawyers, especially in 
criminal cases (European Union Advisory Mission to Ukraine, 2020). Judges were encouraged to use telephone and video hearings as much as possible, and Skype was installed on the laptops of court officials (Williams \& Johnson, 2020).

The spread of the Covid-19 pandemic has affected justice in Ukraine as well. The changed can be seen in the Law of Ukraine "On Amendments to Certain Legislative Acts of Ukraine Aimed at Providing Additional Social and Economic Guarantees in Connection with the Spread of Coronavirus Disease (Covid-19)" dated March 30, 2020, $\mathrm{n}^{\circ}$ 540, the Code of Administrative Procedure, Economic Procedure, the Commercial Code, the Civil Procedure and Civil Code, the Labor Code, and the Family Code. The changes concern, in particular: (i) automatic extension of the terms of appeal to the court and procedural terms in civil, economic, and administrative cases for the duration of the quarantine; (ii) extension for the duration of the quarantine period of appeal; (iii) extension of the statute of limitations defined by the Civil Code of Ukraine and the Economic Code of Ukraine; and (iv) granting participants in civil, economic, and administrative cases the right to participate in court proceedings in the mode of videoconference outside the court building using their own technical means.

According to the above mentioned Law, for the duration of the quarantine measures, all procedural terms determined by the procedural codes of Ukraine have been extended, excluding the Criminal Procedure Code of Ukraine. In addition, it is normalized that any period established by the court in its own decision cannot be less than the period of quarantine. At the same time, it should be noted that the normative act did not take into account the possibility of extending the quarantine for a longer period of time, and therefore laid the foundation for blocking the judicial system.

Certain changes have also taken place in the implementation of the procedural principles of the judiciary, such as due process, adversariness, transparency, reasonableness of the terms of court proceedings, collegial and individual court proceedings, people's participation in the administration of justice, ensuring the human right to legal assistance, binding and motivated court decisions. In the context of the spread of the pandemic, difficulties have arisen, in particular, in the implementation of the principles of due process, adversariness transparency, because when judges take justice in open court sessions with the direct participation of the parties to the process, there is a threat to the life and health of judges and participants in court sessions.

It should be noted that in the implementation of the principles of publicity, openness, many courts have already accumulated positive experience, which was useful in the context of the introduction of quarantine 
measures. Thus, since 2004, the ECHR has been publishing decisions and rulings of the court in electronic form, and a message to the parties about the decisions made has been published since 2016. In total, during the quarantine measures, which continued in France from March 16 to May 10, the ECHR adopted 39 decisions (Supreme Court of Ukraine, 2020). In Australia, the New South Wales Supreme Court went live in Queensland and filed a property damage claim back in 2019 (Legg \& Song, 2020). With the spread of the pandemic in this country, in order to increase the openness of justice, accessibility to a wider public, not only within the court, they expanded the use of the streaming service YouTube.

The widespread use of information technologies in legal proceedings transforms the judicial procedure, and, in fact, leads to the formation of "cyber justice" (European Commission for the Efficiency of Justice, 2020), which, on the one hand, enables the judiciary to carry out its work, and on the other, its excessive use can lead to negative consequences. While recognizing the important role of technological and telecommunication infrastructures in administering justice in a pandemic spreading, it is necessary to take into account certain difficulties faced by the participants: (i) insufficient staffing of the courts themselves; (ii) imperfect software (for judicial procedures); (iii) insufficient bandwidth of the Internet and its availability in suburban and regional areas where lawyers, parties, witnesses are located; and (iv) phobias, especially among older people, regarding modern technologies.

Under such conditions, it is necessary, in particular, to provide a clear legal basis for the implementation of information technologies in legal proceedings; systematically assess the impact of the use of information technologies on the administration of justice, protection of personal data, and, if necessary, make adjustments.

In the context of the spread of the Covid-19 pandemic, the implementation of the principle of people's participation in the administration of justice has not only become more complicated but has actually become impossible in most cases. Thus, in Australia, the provisions of the Law require that the person accused appear before the court, unless the court decides otherwise. Given that jury trials require citizens to sit in close proximity to each other, new jury trials have been postponed across Australia due to the significant risk of a pandemic spreading. In addition, the Covid-19 Law Amendment Act 2020 introduced the provisions of 22C of the Evidence (Audio and Audiovisual Links) Act 1998 (Travesi, 2020).

Other issues related to the implementation of the principles of the judiciary and its functioning in fundamentally new conditions also appeared before the judiciary. It is about transforming the monitoring of document 
circulation, its quality, and implementation because properly functioning case management systems and mechanisms for collecting statistical data on the functioning of the courts are of particular importance during a health crisis. In conditions when the number of pending cases and delays in court proceedings may increase in the courts, the courts require additional human resources and an increase in budget support.

\section{II.4. Ongoing Work to Streamline the Administration of Justice in a Pandemic}

In the context of the spread of the Covid-19 pandemic, along with the observance of the principles of the judiciary, it is extremely important to unite efforts and expand cooperation of the European judicial community to ensure proper and impartial justice, a joint search for optimal legal means to improve legal proceedings, based on international and European legal standards and at the same time taking into account new threats and challenges. We are talking in particular about the conclusions, recommendations of the European Commission on the Effectiveness of Justice of the Council of Europe, the Consultative Council of European Judges, as well as the systematic holding of videoconferences, seminars, and other communication activities between courts at the national, European and international levels to sharing positive experience in administering justice in the context of the spread of the Covid-19 pandemic.

In this context, the European Commission for the Effectiveness of Justice Council of Europe's "Declaration on Long Lessons and Challenges Faced by the Judiciary During and After the Covid-19 Pandemic", adopted at a special extramural plenary meeting in Strasbourg on 10 June 2020. In the Declaration, the European Commission for the Effectiveness of Justice (2020) focuses on such important principles as: (i) human rights and the rule of law; (ii) access to justice; (iii) safety of persons; (iv) monitoring of workflow, quality and implementation; (v) cyber justice; (vi) training; and (vii) progressive justice, and emphasizes that over the past 15 years it has developed its own methodology, tools, and best practices to analyze and maintain the effectiveness and quality of the judicial systems, which can be useful during the crisis.

Special attention should be paid to the provision on the need to develop a strategy for the transformation of the judiciary in order to use the advantages of recently adopted decisions, an innovative procedure for action in emergencies, and at the end - a revision of some aspects of the traditional functioning of the courts (relations with the media, the level of application of new technologies, more often resorting to alternative settlement disputes, 
in particular, mediation), maintaining a dialogue between all institutions of the justice system, as well as between judges, prosecutors, court officials, lawyers, executive officers, notaries, mediators, and experts, during a health crisis.

Members of the Consultative Council of European Judges also expressed their positions on the specifics of administering justice in the context of the spread of the Covid-19 pandemic. Summarizing the recommendations of the Consultative Council members, its chairman and judge Batetto (Council of Europe, 2020), the positions of experts and judges from Italy, Germany, Great Britain, Ukraine, Finland, there are several key aspects and lessons that need to be taken into account by judicial systems and judges in connection with the spread of Covid-19: (i) the use of new legal means in strict compliance with human rights obligations; (ii) the need to strike a balance between public safety and the enjoyment of fundamental rights and freedoms; (iii) maintaining the independence of the judiciary; (iv) preventing the politicization of courts; and (v) the use of new modern technologies to facilitate telecommuting and conducting trials based on teleconferences, remote hearing of witnesses, experts, defendants; consider the possibility of using measures not related to imprisonment, reduction of prison sentences to avoid overcrowding in prisons and the spread of a pandemic; suspension of further training activities, organization and implementation of online training courses at national and European levels (Council of Europe, 2020).

It should be noted that, despite certain conclusions and lessons on the administration of justice and the protection of human rights, not all recommendations can be taken into account in national judicial systems, given their particularities. For example, in Germany, videoconferencing is prohibited due to personal data protection rules. In Finland, videoconferencing is mainly used in civil cases with the consent of all parties (European Union Advisory Mission to Ukraine, 2020).

Common to the members of the European Commission for the Efficiency of Justice (2020) and the Consultative Council of European Judges is the thesis that the administration of justice in a pandemic, along with ensuring the implementation of the rule of law, protecting human rights, is important to maintain public confidence in the judiciary. «Trust in justice must remain even in times of crisis». The same opinion is shared by foreign scholars, they note: «Hearing a case in court is a public demonstration of the rule of law-impartiality, fair procedures, public disputes and arguments. Justice must be ensured to ensure public confidence in the administration of justice» (Legg \& Song, 2020). 
The above provisions and recommendations of European judicial institutions are important not only for national courts and judges but also for civil society, ordinary citizens, since they confirm the indisputable value of the rule of law, human rights, justice in modern democratic countries, despite new challenges and threats caused by the spread of a pandemic.

A positive example of the exchange of accumulated experience in administering justice in the context of the spread of the Covid-19 pandemic is several events held between judicial authorities, judges from Ukraine, and foreign countries. Therefore, on April 17, 2020, judges from the European Union shared their practical experience of administering justice during a pandemic with their Ukrainian colleagues (European Union Advisory Mission to Ukraine, 2020). On June 3, 2020, the Ukrainian-Canadian Judicial Reform Support Project organized and conducted a Zoom video conference on the topic: "Ensuring the Continuous Administration of Justice in the Coronavirus Epidemic: Canadian and Ukrainian Experience", which took place as part of the component continuous work of the court. Ukrainian and Canadian judges discussed: (i) the approaches to organizing the work of the court in the context of the coronavirus epidemic (Covid-19) and the quarantine announced by the Government; (ii) the advantages of using telecommunication and electronic technologies in the implementation of legal proceedings; (iii) the issue of balance between ensuring the principle of openness of the judicial process and the risk of loss of citizens' confidence in the court and the judicial process; (iv) issues of opposition to the submission by the parties of the process of numerous requests to postpone the consideration of the case concerning quarantine; and (v) the expediency of making changes to procedural legislation, in particular, of Ukraine.

The exchange of experience in managing in court during an emergency, experience in coordinating actions, communicating was not only a discussion of problematic issues but also examples of foreign procedural documents, from which one can take something useful for administering justice in Ukraine in the context of the coronavirus epidemic (Judicial power of Ukraine, 2020).

Also noteworthy is the first webinar initiated by the European Court of Human Rights for members of the network of national high courts for administering justice in a pandemic, which took place on July 15, 2020, its participants discussed the problems of administering justice in a pandemic caused by Covid-19, the associated risks in ensuring the right to a fair trial, which requires uniting efforts and expanding cooperation of the European judicial community in order to ensure an independent and impartial justice in the protection of human rights (Supreme Court of Ukraine, 2020). 
Compliance with the principles of the judiciary and taking into account the positive foreign experience of administering justice in modern conditions becomes important and given the fact that during the introduction of quarantine measures, a new practice of constitutional jurisdiction bodies is formed in relation to restrictions on human rights and freedoms. Analysis and generalization of the foreign experience of the practice of constitutional jurisdiction bodies of foreign countries shows that the courts considered cases on the restriction of such human rights and freedoms as freedom of movement (Bosnia and Herzegovina, the Republic of Slovenia, the Czech Republic) the right to peaceful assembly (Germany) the right to property (wages' fee; Republic of North Macedonia). When making the decision, the bodies of constitutional jurisdiction were based on the fact that restriction of freedom of movement is unconstitutional and violates human rights; a significant part of the restrictions are not limited in time; there is no obligation at the regulatory level to regularly review them (Bosnia and Herzegovina, Republic of Slovenia).

\section{ConClusions}

Analysis and generalization of foreign and Ukrainian experience in the administration of justice and directions for its improvement in the context of the spread of the Covid-19 pandemic through the prism of the principles of the judiciary allow us to draw the following conclusions:

(i) The global spread of the Covid-19 pandemic has impacted the administration of justice in modern countries. In a fundamentally new environment, the judiciary is called upon to ensure justice, the balance of interests of society and individuals, public safety, and the right to a fair trial. In the short term, national and international judicial institutions, along with these, will face new challenges and threats, including, in particular, as: a) a significant increase in the burden on the courts in connection with the economic crisis, violation of social, economic, political, cultural rights of citizens; b) the need for a prompt organizational response to new challenges; and c) limiting financial and material resources and rethinking funding strategies.

(ii) The spread of the Covid-19 pandemic has, to varying degrees, influenced the implementation of the basic and organizational principles of the judiciary. Despite the complex and contradictory conditions, the criteria of justice remain international and European standards of legal proceedings, enshrined in a number of international legal acts. Among the basic principles of the judiciary, the most difficult was the observance of the principles of 
justice, the rule of law, legality, and transparency. The content of these principles is being transformed, and their implementation largely depends on the specifics of national judicial systems. The common position for leaders of the judiciary and the international judicial community is that a public health emergency cannot be used as a pretext for human rights violations and that new legal remedies must be applied in strict accordance with the principles of the rule of law, the rule of law and the obligations of rights person.

(iii) As a result, unprecedented restrictions on human rights and tough quarantine measures taken by the governments of many states have become the subject of an appeal in the constitutional jurisdictions of some countries, which in their decisions focused on the implementation of only those measures that are legal, proportionate, necessary, non-discriminatory, had specific purpose and duration in time.

(iv) The spread of the Covid-19 pandemic has significantly complicated the implementation of such organizational principles of the judiciary as the availability of justice and ensuring the right to review a judgment. Among the procedural principles of the judiciary, the principles of due process, transparency, and reasonableness of the timing of judicial proceedings have transformed. The implementation of these principles has caused the need to introduce innovative measures and wider use of IT technologies in legal proceedings, one of the consequences of which is the formation of "cyber justice". The modern experience of administering justice indicates the need to introduce innovative approaches to organizing the functioning of courts, expanding dialogue between all institutions of the justice system, and using alternative dispute resolution, in particular, mediation.

(v) In the current difficult conditions of the spread of the Covid-19 pandemic, we believe that it is necessary not only to make every effort to maintain the standards of justice, but also extremely important to take into account the positive foreign experience in the administration of justice, pool efforts and expand cooperation of the European judicial community (in particular, members and judges of the European Commission on the Effectiveness of Justice, the Consultative Council of European Judges, the European Court of Human Rights) to ensure proper and impartial justice, joint search for optimal legal means to improve legal proceedings, based on international and European legal standards and at the same time take into account new threats and challenges. 


\section{REFERENCES}

Australia. (2020). Covid-19 Law Amendment Act. In https://www.parliament.nsw.gov.au/bills/Pages/bill-details.aspx?pk=3741.

Boot, A., Carletti, E., Haselmann, R., Kotz, H. H., Krahnen, J. P., Pelizzon, L., Schaefer, S. \& Subrahmanyam, M. (March 24, 2020). The coronavirus and financial stability. Vox. In https: //voxeu.org/content/coronavirus-and-financial-stability.

Bos, v. d. K., Velden, v. d. L. \& Lind, E.A. (2014). On the Role of Perceived Procedural Justice in Citizens 'Reactions to Government Decisions and the Handling of Conflicts. Utrecht Law Review, 10(4), 1-26. In https: //www.utrechtlawreview.org/articles/abstract/10.18352/ulr.287.

Bosnia and Herzegovina. Constitutional Court. (2020). Decision AP 1217/20. In http://www.ustavnisud.ba/dokumenti/_en/AP-1217-20-1234093.pdf.

Brennan, D. (2020). Fines, jail time and sackings: what happens when people break coronavirus quarantines around the world. Newsweek. In https: //www.newsweek.com/fines-jail-time-sackingswhat-happens-people-breakcoronavirus-quarantines-around-world-1492947.

Center on International Cooperation. (2020). Pathfinders for Peaceful, Just and Inclusive Societies, Justice in a Pandemic_-Briefing One: Justice for All and the Public Health Emergency. In https://www.justice.sdg16.plus/.

Centers for Disease Control and Prevention. (2019). What Law Enforcement Personnel Need to Know about Coronavirus Disease 2019 (Covid-19). In https://www.cdc.gov/coronavirus/2019-ncov/community/guidance-lawenforcement.html.

Civicus. (2020). States should put human rights at the center of all responses to Covid-19. In https://www.civicus.org/index.php/media-resources/media-releases/4357civicus-statesshould-put-human-rights-at-the-centre-of-all-responses-to-covid$19 /$.

Council of Europe. (2020). How should judges respond to the Covid-19 challenges and what lessons should they learn? Advisory Council of European Judges. In https://www.coe.int/ru/web/portal/Covid-19.

CrisisGroup. (2020). Covid-19andConflict: SevenTrends to Watch. In https://www.crisisgroup.org/global/sb4-Covid-19-and-conflictseven-trendswatch.

European Commission for the Efficiency of Justice (CEPEJ). (2020). Lessons Learned and Challenges Facing the Judiciary during and Beyond the Covid-19 Pandemic: Declaration. In https://rm.coe.int/cepej-declaration-on-lessonslearned-cepej-2020-8rev/16809ede8b.

European Union Advisory Mission to Ukraine (EUAM). (April 17, 2020). Justice in times of a pandemic, EU judges shared their practical experience with Ukrainian colleagues. In https://www.euam-ukraine.eu/ua/news/9479/. 
Justice in the Covid-19 era Through the Prism of Judicial Power

Gaviria, P. (April 3, 2020). Police report jump in domestic violence cases amid coronavirus crisis. Komo News. In https://komonews.com/news/local/policereport-jump-in-domestic-violence-report-amid-coronavirus-crisis.

Gorodovenko, V. V. (2012). Principles of the Judiciary. Kharkiv: Right.

Graham-Harrison, E., Giuffrida, A., Smith H. \& Ford, L. (March 28, 2020). Lockdowns around the world bring rise in domestic violence. The Guardian. In https://www.theguardian.com/society/2020/mar/28/lockdowns-world-risedomestic-violence;

Guterres, A. (2020). Covid-19 pandemic and human rights. United Nations. In https://www.un.org/ru/coronavirus/we-are-all-together-human-rights-andCovid-19-response.

Kupchan, C. A. (April 2, 2020). Trump's Covid-19 lapse gives China an opening. CNN. In https://edition.cnn.com/2020/04/02/opinions/trump-covid-china-charleskupchan-opinion/index.html.

Legg, M. \& Song, A. (2020). The courts and the pandemic: the role and limits of technology. LSJ Online. In https://lsj.com.au/articles/the-courts-and-thepandemic-the-role-and-limits-of-technology/.

North, A. (March 26, 2020). When home is not safe: What the coronavirus pandemic means for domestic violence survivors. In https://www.vox.com/2020/3/26/21193814/coronavirus-domesticviolenceshelters-Covid-19-abuse;

Office of the High Commissioner. (2020). Urgent action needed to prevent Covid-19: rampaging through places of detention. In https://www.ohchr.org/EN/NewsEvents/Pages/DisplayNews.aspx?NewsID=25 745\&LangID=E.

Organisation for Economic Cooperation and Development (OECD). (March 2, 2020). Coronavirus: the world economy at risk. In https://www.oecd.org/economicoutlook/.

Organization for Security and Co-operation in Europe. (1990). Copenhagen Meeting of the OSCE Human Dimension Conference. In https://www.oscepa.org/documents/election-observation/election-observationreports/documents/1344-osce-copenhagen-document-1990-eng/file.

Republic of Macedonia. Constitutional Court. (2020). Decision U.no.44/2020 and U.no.50/2020. In http://ustavensud.mk/?p=19030.

Seregin, V. (2015). Rule of law: modern ideas about the essence and content of the constitutional principle. Legalitas. In http://legalitas.com.ua/ua/ukr-v-seroginverxovenstvo-prava-suchasni-uyavlennya-pro-sutnist-ta-zmist-konstitucijnogoprincipu/.

Travesi, F. (March 27, 2020). Justice in the Era of Covid-19: Our Global Responsibility. International Center for Transitional Justice. In https://www.ictj.org/news/justice-era-Covid-19-our-global-responsibility. 
Ukraine. (2020). On amendments to some legislative acts of Ukraine aimed at providing additional social and economic guarantees in connection with the spread of coronavirus disease (Covid-19): Law 540. In https://zakon.rada.gov.ua/laws/show/540-20\#Text.

Ukraine. (2020). On amendments to the Economic Procedural Code of Ukraine, the Civil Procedure Code of Ukraine, and the Code of Administrative Procedure of Ukraine on the course of procedural timeframes during the quarantine established by the Cabinet of Ministers of Ukraine to prevent the spread of coronavirus disease (Covid-19): Law. In https://zakon.rada.gov.ua/laws/show/731-20\#Text.

Ukraine. Judicial Power. (June 4, 2020). Canadian and Ukrainian experiences in the administration of justice in the context of the Covid-19 pandemic. In https://od.arbitr.gov.ua/sud5017/pres-centr/general/949472/.

Ukraine. Supreme Court. (2020). A webinar of the network of the highest courts of the ECHR on the administration of justice in a pandemic was held. In https://supreme.court.gov.ua/supreme/pres-centr/news/968811/.

United Kingdom. (2020). Guideline PD51ZA. In https://www.justice.gov.uk/courts/procedure-rules/civil/rules/practice-direction51za-extension-of-time-limits-and-clarification-of-practice-direction-51ycoronavirus.

United Nations. (1948). Universal Declaration of Human Rights. In https://www.un.org/en/universal-declaration-human-rights/.

United Nations. (1950). Convention for the Protection of Human Rights and Fundamental Freedoms as amended by Protocols $n^{\circ} 11$ and 14 . In https://www.echr.coe.int/documents/convention_eng.pdf.

United Nations. (1966). International Covenant on Civil and Political Rights. In https://www.ohchr.org/EN/ProfessionalInterest/Pages/CCPR.aspx.

United Nations. (1985). Basic Principles on the Independence of the Judiciary. In https://www.un.org/ruleoflaw/blog/document/basic-principles-on-theindependence-of-the-judiciary/.

Williams, D. \& Johnson, D. (2020). Covid-19: Litigation in the Time of a Pandemic. Dac Beachcroft. In

https://www.dacbeachcroft.com/en/gb/articles/2020/march/Covid-19-litigationin-the-time-of-a-pandemic-latest-updates/.

World Health Organization. (2020). Preparedness, prevention and control of Covid-19 in prisons and other places of detention: Interim guidance. In http://www.euro.who.int/data/assets/pdf_file/0019/434026/Preparednessprevention-and-control-of-Covid-19-inprisons.pdf. 